\title{
Energiakustannusten säästö viljankuivauksessa
}

\author{
Timo Lötjönen ${ }^{1)}$ ja Pellervo Kässi ${ }^{1)}$ \\ ${ }^{1)}$ Maa- ja elintarviketalouden tutkimuskeskus, Tutkimusasemantie 15, 92400 Ruukki \\ timo.lotjonen@mtt.fi,pellervo.kassi@mtt.fi
}

\section{Tiivistelmä}

Polttoöljyn litrahinta on parin viime vuoden aikana vaihdellut 45 ja 85 sentin välillä (alv. $0 \%$ ). Polttoaine muodostaa merkittävän osan viljankuivauksen muuttuvista kustannuksista. Puintikosteudeltaan $21 \%$ viljassa 10 sentin muutos öljyn hinnassa muuttaa kuivauskustannusta $n .1,3$ $€ /$ t. Vaikka öljyn hinta on laman myötä asettunut siedettävälle tasolle, todennäköinen kehityssuunta öljyn ja muunkin energian hinnalle on nouseva. Viljankuivauksessa energian säästökeinoja on lukuisia, joita yhdistelemällä voidaan kuivauslaskussa säästää merkittävästi. Myös kotimaisten polttoaineiden käyttö on entistä kannattavampaa.

Helpoin tapa säästää viljansäilönnän kustannuksista on luopuminen kuivaamisesta kokonaan. Kosteana säilötty vilja säilyttää rehuarvonsa lähes kuivan veroisesti. Teknisten rajoitteiden vuoksi tuoresäilötty vilja soveltuu lähinnä tilojen omaan käyttöön ja rajoitetusti tilojen väliseen kauppaan. Kuivausta siis tarvitaan edelleen.

Itse kuivausprosessin järkeistämiseen on kehitetty lukuisia keinoja. Puskurikuivureilla voidaan parantaa kuivaamokoneiston käyttöastetta. Puskurikuivuri myös mahdollistaa energian säästön korjuutyön aikaistumisen kautta. Kuivaussiilon ja tuloilmaputken lämpöeristämisellä on saatu mittauksissa noin $10 \%$ energiansäästö. Kuivausilman lämpöä, kuivausilman määrää ja viljan kiertonopeutta nostamalla saadaan kuivumisesta tehokasta ja tasaista, jolloin energiaa säästyy. Kuivausilman lämpötilan nostaminen 70 asteesta 100 asteeseen alentaa kuivurin polttoaineenkulutusta 10-15 \%. Lämpötilan nosto myös kasvattaa kuivauskapasiteettia nopeuttaessaan kuivumista.

Polttoöljyn korvaamiseen soveltuvat puuhakkeen ja turpeen polttolaitteet ovat kehittyneet huomattavasti viime vuosina. Automatiikan ansiosta niiden toimivuus ja säädettävyys lähestyvät öljypoltinten tasoa. Lämminilmakuivureiden lämpötehontarve on suuri (200 - $1000 \mathrm{~kW})$, minkä vuoksi kiinteällä polttoaineella toimivan lämpökeskuksen hankintahinta on korkea. Laitoksen hankintahintaa kompensoivat kiinteiden polttoaineiden öljyä matalammat hinnat. Puuhakkeen energian hinta on vain $20-40 \%$ polttoöljyn hinnasta.

Laadituissa investointilaskelmissa vertailtiin polttoöljyä ja kiinteää polttoainetta käyttävän kuivaamon lämmitysjärjestelmän nettokassavirtojen erotuksien nykyarvoja $5 \%$ :n laskentakorkokannalla ja kymmenen vuoden laskentajaksolla. Laskelmassa kuivaussiiloltaan $30 \mathrm{~m}^{3}: \mathrm{n}$ kuivurin lämmönlähteeksi valitaan öljylämmitysjärjestelmä tai lämpökontti, jossa on stokerisyöttöinen ilmalämmitysuuni. Lämpökonttia ei oleteta siirrettäväksi muualle kuivauskauden päätyttyä. Käytetyillä laskentaoletuksilla investointi ostohaketta käyttävään lämpölaitokseen osoittautui kannattavaksi öljyn hinnan kohotessa yli $66 \mathrm{c} / 1$ kiinteän polttoaineen hinnan pysyessä ennallaan. Oman hakkeen tai palaturpeen käyttö olisi öljyä edullisempaa jo öljyn hinnan ylittäessä 55 - 58 c/l.

Asiasanat: viljankuivaus, energian säästö, kiinteä polttoaine, investointilaskelma 


\section{Onko viljan kuivaus välttämätöntä?}

Suurin osa maassamme tuotetusta viljasta on rehuviljaa, joka voitaisiin säilöä tuoreena ilmatiiviisti tai murskesäilönnällä. Esimerkiksi sikojen ruokinnassa ei ole kovin viisasta, että vilja ensin kuivataan varastointia varten ja seuraavaksi se kastellaan liemiruokintaan sopivaksi. Laskelmien mukaan tuoresäilönnän kustannukset ovat vain noin puolet lämminilmakuivauksen kustannuksista (Palva \& Lötjönen 2005). Tuoreena säilötty vilja soveltuu lähinnä tilojen omaan käyttöön ja rajoitetusti tilojen väliseen kauppaan.

Kuivalla viljalla on tuoreeseen nähden ylivertaisia ominaisuuksia; sen säilyvyys, liikuteltavuus ja kehittyneet markkinat. Leipä- ja siemenvilja täytyy aina kuivata, eikä keskusliikkeiden kautta tapahtuva rehuviljakauppa toimi tuoreella viljalla. Näistä syistä viljan kuivaustakin on edelleen kehitettävä.

Kuivauksen kustannuksista on tyypillisesti noin $2 / 3$ kiinteitä, eli rakennuksen ja koneiden hankinnasta, omistamisesta ja ylläpidosta johtuvia (Palva \& Lötjönen 2005). Suurimmat säästöt saavutetaan suunnittelemalla kuivaamon rakenteet mahdollisimman yksinkertaisiksi. Toimivaa ja kapasiteetiltaan riittävää viljankuivaamoa ei yleensä kannata lähteä yksinkertaistamaan tai muuttamaan tuoresäilönnäksi, koska valtaosa kustannuksista on syntynyt jo investointivaiheessa.

\section{Tarpeettoman kuivauksen välttäminen ja kuivauksen säätäminen}

Polttoaine muodostaa merkittävän osan viljankuivauksen muuttuvista kustannuksista. Puintikosteudeltaan $21 \%$ viljassa 10 sentin muutos öljyn hinnassa muuttaa kuivauskustannusta $\mathrm{n}$. 1,3 $€ / t$ (Palva ym. 2006). Vilja tulisi puida mahdollisimman kuivana, jotta vettä on vähemmän haihdutettavaksi. Puintikosteustavoite tulisi olla alle $20 \%$ :n. Alhainen tavoitekosteus vähentää kiinnostusta myöhäisiin lajikkeisiin ja leipäviljaan, joiden puintikorkeus on yleensä aikaisia rehulajikkeita korkeampi.

Viljan kuivaaminen yöllä lisää kuivurin öljynkulutusta 5 - $10 \%$ päiväkuivaukseen verrattuna. Toisaalta tiukasti mitoitetulla kuivauskapasiteetilla voidaan joutua ojasta allikkoon odoteltaessa parhaita puintikelejä tai kuivattaessa ainoastaan päivällä. Syksyn edetessä kosteiden ilmojen todennäköisyys kasvaa.

Viljaa saadaan kuivattavaksi tasaisemmin puintikauden aikana käyttämällä kuivaamattoman viljan varastointiin ns. puskurikuivureita. Puskurikuivuri voi olla esimerkiksi viljavaunu, joka on varustettu puhaltimella. Puskurikuivurissa viljaa voidaan säilöä useita päiviä, jopa viikkoja odottamassa varsinaisen kuivaamon vapautumista. Eräiden laskelmien mukaan puskurikuivureilla voitaisiin säästää kuivausenergiaa jopa 20 - 30\% korjuutyön aikaistumisen myötä (Ahokas \& Koivisto 1983). Kustannussäästö voi kuitenkin jäädä pieneksi, sillä puskureiden rakentaminen maksaa ja niiden täyttö ja tyhjennys aiheuttaa lisätyötä.

Kuivaamon lämpöhukkia voidaan vähentää lämpöeristämällä kuivaussiilo ja tuloilmaputki. Lämpöeristämisellä on saavutettu noin 10 \% energiansäästö (Ahokas \& Koivisto 1983). Tuloilmaputken eristäminen on pienehkö vaiva saatuun hyötyyn nähden. Kuivaussiilon eristämisestä saadaan eniten hyötyä täysin ulkona seisovissa kuivureissa, joissa tuuli pääsee vapaasti jäähdyttämään peltipintoja.

Kuivattaessa viljaa alle $14 \%$ :n kosteuteen hukataan paljon energiaa. Energian kulutus kosteuden haihduttamiseen kasvaa viljan kosteuspitoisuuden alentuessa. Ylikuivauksen välttämisellä on arvioitu voitavan säästää $10-20 \%$ kuivausenergiaa. Varsinkin yksin puitaessa, olisi toimiva ja luotettava pysäytysautomatiikka hyvin tarpeellinen investointi. Tulipinnoille kertynyt eristävä noki ja polttimen väärä ilmamäärä heikentävät uunin hyötysuhdetta merkittävästi. Kuivuriuunin säännöllisellä puhdistamisella ja huollolla voidaan säästää keskimäärin $5-10 \%$ energiaa (Ahokas \& Koivisto 1983).

Kuivaamon oikeat säädöt ovat ensisijainen tarkastelukohde, oikeilla säädöillä saadaan jo tehdystä investoinnista suurin hyöty. Kuivausilman lämpö, kuivausilman määrä ja viljan kiertonopeus tulisi säätää suhteellisen suuriksi, tällöin kuivuminen on tehokasta ja tasaista ja energiaa säästyy. Viljan pitäisi kiertää vähintään kerran tunnissa (Lötjönen \& Pentti 2005).

\section{Korkealla kuivauslämmöllä lisää kapasiteettia}

Nykyään palomääräykset eivät enää rajoita kuivauslämpötilaa, vaan korkein mahdollinen kuivauslämpö on sovittavissa kuivurivalmistajan, palotarkastajan ja vakuutusyhtiön kanssa. 
Turvallisinta korkean kuivauslämmön (yli $80^{\circ} \mathrm{C}$ ) käyttö on sitä varta vasten suunnitellussa kuivurissa. Vanhoissakin kuivureissa kuivauslämpöä voidaan nostaa, mutta uunin suurinta sallittua öljymäärää ei saa ylittää, koska tällöin riskinä on uunin puhkipalaminen.

Viljan kuivaaminen 100-asteisella ilmalla 70 -asteisen sijasta vähentää kuivurin polttoaineenkulutusta 10-15\% (Suomi ym. 2003). Lämpötilan nosto myös nopeuttaa kuivumista eli lisää kuivauskapasiteettia. Lämpötilaa ei useinkaan kannata nostaa yli $100{ }^{\circ} \mathrm{C}$ :een, koska lisähyötyä ei yleensä enää saada, mutta lämpö kannattaisi nostaa noin $80-90{ }^{\circ} \mathrm{C}$ :een vanhoissakin kuivureissa. Viljan itävyys ei vielä yleensä laske $80^{\circ} \mathrm{C}$ :ssa, mikäli vilja kiertää vähintään kerran tunnissa. Useissa käyttötarkoituksissa ei viljan itävyydellä ole mitään merkitystä. Lämpötilan nosto kasvattaa kuivurin palamisen riskiä. Toimivalla automatiikalla varustetun siivotun ja huolletun kuivaamon palaminen on kuitenkin hyvin epätodennäköistä, jos uunin suurinta sallittua öljymäärää ei ylitetä.

Jatkuvatoimiset kuivurit ovat Suomessa toistaiseksi harvinaisia, koska ne vaativat suuret määrät samanlaatuista viljaa jatkuvasti kuivattavaksi. Jatkuvatoimiset kuivurit eivät myöskään sovi kovin hyvin kostean, yli $30 \%$ :sen viljan kuivaamiseen. Niillä voitaisiin kuitenkin säästää kuivausenergiaa jonkin verran, sillä niissä uuni on jatkuvasti päällä, eikä energiaa tuhlaannu uunin ja kennoston jäähdyttämiseen ja uudelleen lämmittämiseen. Suomen oloihin on kehitelty paremmin soveltuvia "puolijatkuvatoimisia" kuivureita. Eräitä niistä voidaan käyttää tilanteen mukaan joko jatkuva- tai erätoimisena. Toisessa ratkaisussa on kaksi erätoimista kuivaussiiloa ja vain yksi yhteinen uuni. Uuni saa olla jatkuvasti päällä, kun toista siiloista kuivataan ja toista tyhjennetään ja täytetään. Näiden energiansäästöstä ei ole mittaustuloksia, mutta kuivauskapasiteetti ainakin nousee.

Kuivuriyhteistyö on laajalle levinnyt maassamme ja enemmänkin sitä voitaisiin vielä harjoittaa. Ennen kaikkea se tuo säästöä kiinteissä kuluissa, mutta mahdollistaa myös energiatehokkaamman teknologian käyttöönoton, kun kustannukset jakaantuvat useamman viljatonnin kesken.

Aurinkokeräimiä ei juuri käytetä lämminilmakuivureissa, mutta keräinten käyttö olisi perusteltua myös niissä. Aurinkokeräimellä voidaan nostaa kuivuriuunin imuilman lämpötilaa jopa 5 ${ }^{\circ} \mathrm{C}$, jolloin se vähentää polttoaineen kulutusta noin $2 \mathrm{l} / \mathrm{h} 250 \mathrm{~kW}$ tehoisessa uunissa (Lötjönen \& Pentti 2005). Suurilla kuivausmäärillä tämä säästö on merkittävä. Aurinkokeräimen rakentamiskustannuksetkaan eivät yleensä ole korkeat.

\section{Kotimaiset polttoaineet lämmönlähteenä}

Puuhakkeen ja turpeen polttolaitteet ovat kehittyneet huomattavasti viime vuosina. Toimivuus ja säädettävyys ovat automatiikan ansiosta jo lähes öljypoltinten tasolla. Jos talouskeskuksen suhteellisen suuritehoinen $(>100 \mathrm{~kW})$ lämpökeskus sijaitsee lähellä kuivuria, voidaan sieltä tuoda kuivurille lämpöä lämpökanaalin avulla ja luovuttaa se radiaattorin kautta öljykäyttöisen kuivurin lisälämmöksi tai korvata öljy näin kokonaan. Järjestelyn kannattavuus on yleensä sitä parempi, mitä lähempänä lämpökeskuksen teho on kuivurin tehontarvetta ja mitä lyhyempi matka lämpöä tarvitsee siirtää. Nämä ratkaisut ovat monesti hyvin kannattavia (Koskiniemi 2009). Toinen vaihtoehto on korvata öljylämmitteinen uuni kokonaan kiinteään polttoaineeseen perustuvalla lämmitysjärjestelmällä.

Koska lämminilmakuivureiden lämpötehontarve on suuri $(200-1000 \mathrm{~kW})$, on tämän tehoisen kiinteän polttoaineen lämpökeskuksen hankintahinta korkea. Kiinteää polttoainetta käytettäessä mekaniikkaa, automatiikkaa ja tilaa tarvitaan enemmän kuin vastaavan tehoisessa öljylämpöjärjestelmässä. Kuivauskausi kestää Suomessa korkeintaan kaksi kuukautta, joten kalliille investoinnille pitäisi löytää kuivurin lämmityksen lisäksi muutakin käyttöä esimerkiksi kasvihuoneen tai läheisen koulurakennuksen lämmittäminen. Maatilan lämmityslähteeksi kuivurin lämpökeskus sopii yleensä huonosti, sillä maatilan rakennusten lämpötarve on usein vain 5 - $20 \%$ viljankuivurin tehontarpeesta. Näin alhaisella teholla lämmitettäessä kuivuriuunin hyötysuhde jää huonoksi.

Vallitsevalla öljyn hinnalla uuden kuivurin varustaminen pelkästään kiinteän polttoaineen järjestelmällä alkaa olla järkevää. Oheisessa laskelmassa kiinteän polttoaineen ja öljykattilan kustannuksia tarkastellaan tilanteessa, jossa ollaan investoimassa uuteen kuivaamon lämmitysjärjestelmään, vaihtoehdot ovat uusi öljyuuni rakennuksineen tai kiinteällä polttoaineella toimiva lämpökontti. Lämpökontissa on stokerisyöttöinen $500 \mathrm{~kW}: n$ ilmalämmitysuuni. Lämpökonttia ei oleteta siirrettäväksi muualle kuivauskauden päätyttyä. Käytetyt laskentaoletukset esitetään taulukossa 1. 
Kiinteän polttoaineen polttolaitteen oletetaan käytössä vaativan enemmän työtä ja sähköä. Kiinteän polttoaineen järjestelmän hankintahinta on lähes kolminkertainen öljyjärjestelmään nähden. Öljy on polttoaineena selvästi kiinteitä polttoaineita kalliimpaa (marraskuussa 2009: $52 € /$ MWh vs. 10 - $20 € /$ MWh) (Taulukko 2). Käytetty kiinteä polttoaine oletetaan voitavan varastoida kuivauskauden ajan joko tilalla olemassa olevassa varastossa, tai esim. kasassa peitettynä. Esimerkin mukaisella 300 tunnin käytöllä hakkeen tarve olisi n. $170 \mathrm{i}-\mathrm{m}^{3}$, joten aivan pieneen tilaan se ei mahdu.

Vaihtoehtojen vertailuun käytetään nettonykyarvomenetelmää, joka on tarkoitettu investointivaihtoehtojen vertailuun. Nettonykyarvomenetelmän mukaan investointi on kannattava, jos kassavirtojen nykyarvo on nolla tai suurempi (Brealey ym. 2006). Kiinteän polttoaineen polttojärjestelmän hankinnasta ja käytöstä muodostuvia tuottoja ja kuluja verrataan öljykäyttöisen uunin aiheuttamiin kustannuksiin. Kiinteän polttoaineen ja öljykäyttöisen vaihtoehtojen kassavirtojen erotuksesta muodostuville nettokassavirroille lasketaan nykyarvo laskentakorkokantaa käyttäen.

Taulukko 1. Lämmitysjärjestelmän investointilaskelman oletukset.

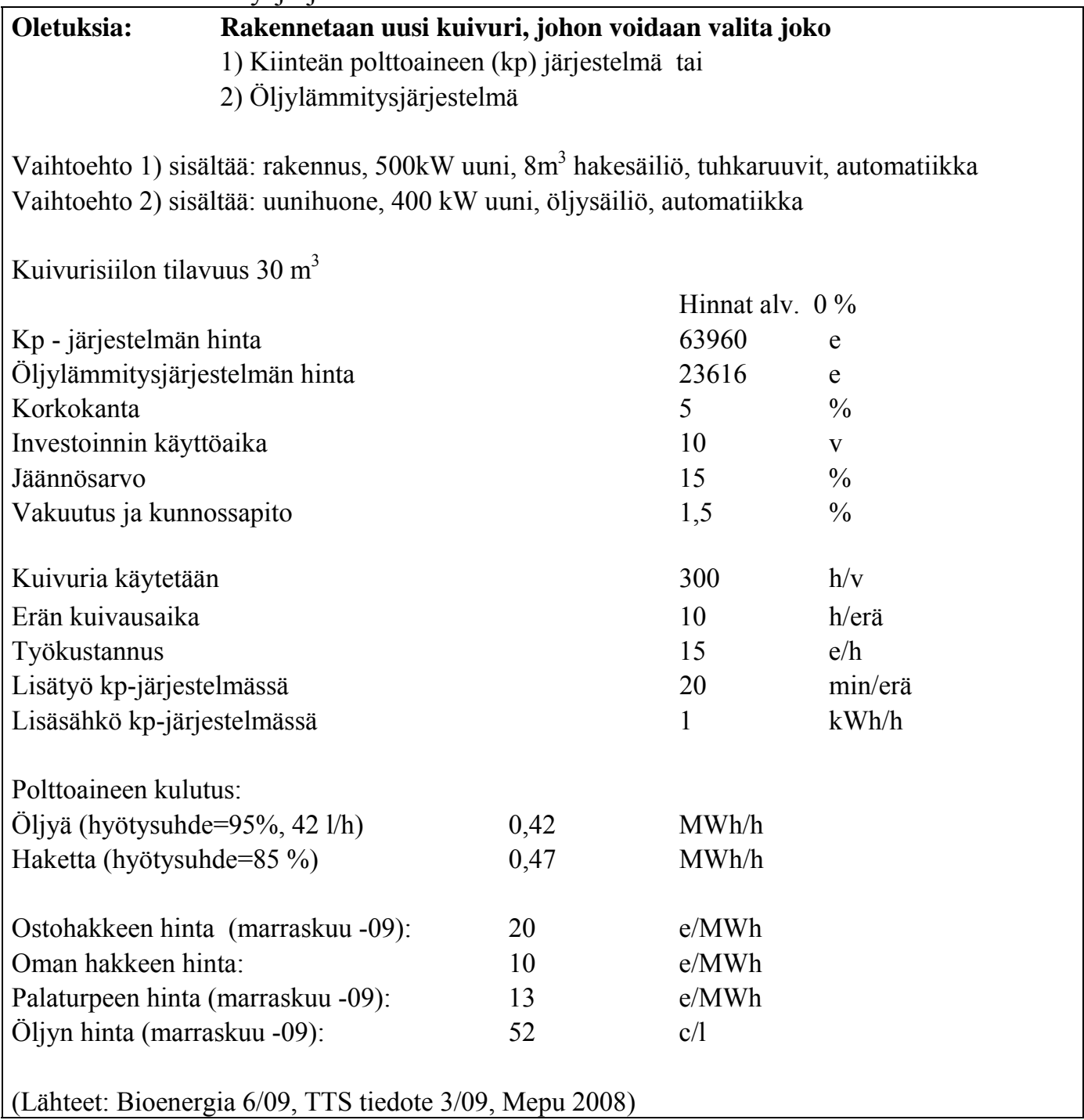

Kuvassa 1 esitetään kiinteän polttoaineen investoinnin nykyarvo kolmella eri kiinteän polttoaineen hinnalla öljyn hintaa muutettaessa. Perusoletuksena käytetyllä $20 € / \mathrm{MWh}$ hinnalla polttoöljyn hinnan kohotessa yli $66 \mathrm{c} / 1$, kiinteää polttoainetta käyttävä lämmitysjärjestelmä muuttuu kannattavaksi. Hinta $10 € / \mathrm{MWh}$ voisi vastata esim. omasta puutavarasta tehdyn hakkeen tekemisestä aiheutuneita muuttuvia kustannuksia. Tällä hinnalla investointi olisi kannattava jo $\mathrm{n}$. $55 \mathrm{c} / 1$ polttoöljyn hinnalla. Palaturpeen hinnalla $13 € / M W h$ kannattavuusraja olisi $58 \mathrm{c} /$ l. Jos kiinteä polttoaine kallistuisi 33 $€ / M W h$ hintaan, investointi muodostuisi kannattavaksi vasta yli $80 \mathrm{c} / 1$ polttoöljyn hinnalla. 
Taulukko 2. Kiinteän polttoaineen järjestelmän (Kp) ja öljylämmitteisen kuivurin kiinteät ja muuttuvat kustannukset (Bioenergia 6 / 09, TTS Tiedote 3 / 09 ja Mepu 2008).

\begin{tabular}{|c|c|c|c|c|}
\hline & & $\mathrm{Kp}$ & Öljy & Erotus \\
\hline Polttoaineen hinta $€ / M W h$ & & 20 & 52 & \\
\hline Kuivurin käyttö h / v & & 300 & 300 & \\
\hline Hankintahinta $€($ alv. $0 \%)$ & & 63960 & 23616 & -40344 \\
\hline Jäännösarvo & & 9594 & 3542 & -6052 \\
\hline Vakuutus ja kunnossapito $1,5 \%$ & & 959,40 & 354,24 & $-605,16$ \\
\hline Lisätyö h / erä & & 0,33 & & \\
\hline Lisäsähkö kWh / h & & 1 & & \\
\hline Lisätyö ja sähkö $€$ / v & & 174 & & -174 \\
\hline Energiakustannus & $\mathrm{c} / 1$ & $€$ & $€$ & $€$ \\
\hline \multirow[t]{9}{*}{ Öljyn hinta } & 40 & 2820 & 5073 & 2253 \\
\hline & 45 & 2820 & 5707 & 2887 \\
\hline & 52 & 2820 & 6595 & 3775 \\
\hline & 60 & 2820 & 7609 & 4789 \\
\hline & 65 & 2820 & 8243 & 5423 \\
\hline & 70 & 2820 & 8877 & 6057 \\
\hline & 75 & 2820 & 9511 & 6691 \\
\hline & 80 & 2820 & 10146 & 7326 \\
\hline & 85 & 2820 & 10780 & 7960 \\
\hline
\end{tabular}

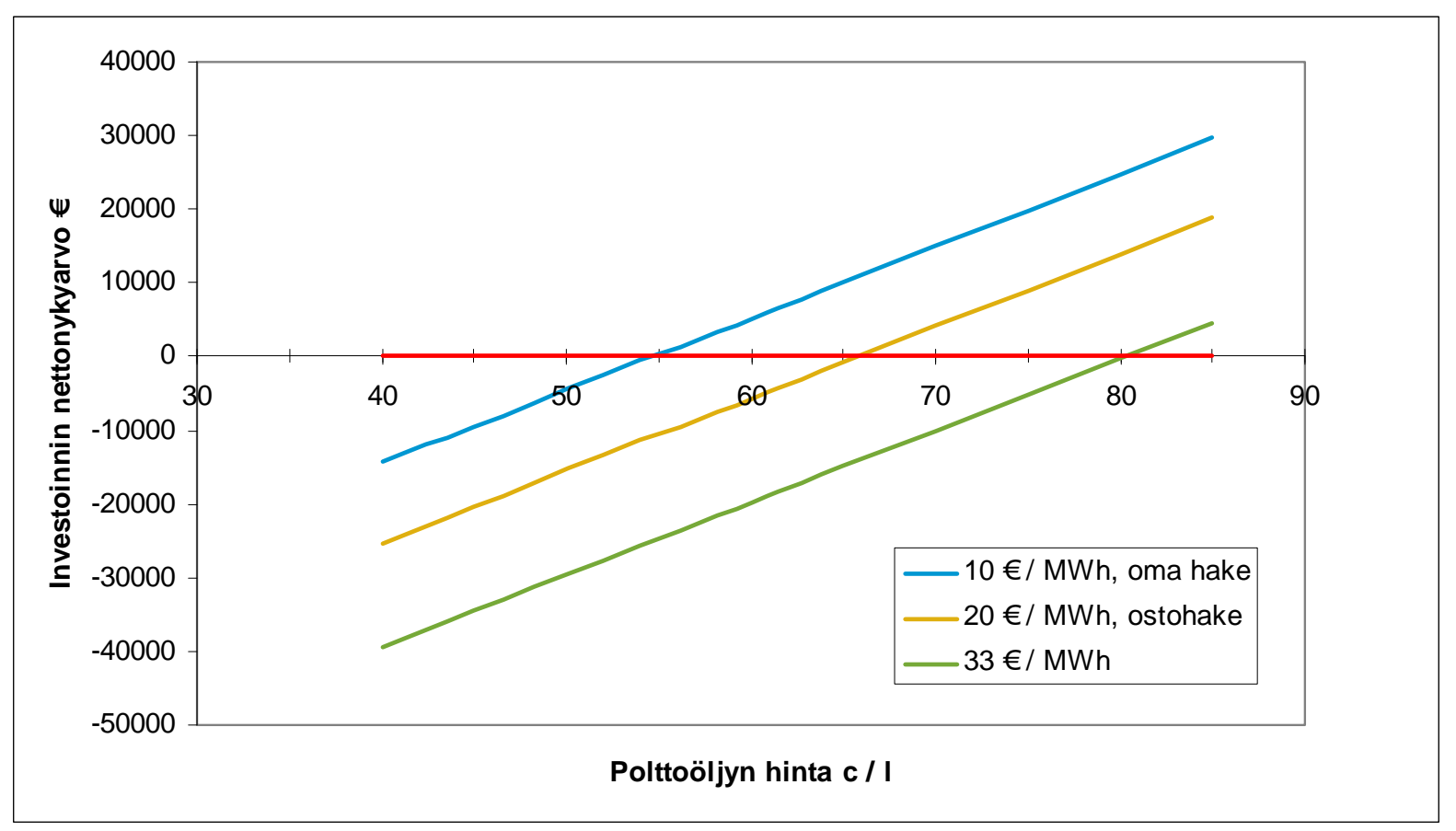

Kuva 1. Kiinteää polttoainetta käyttävän kuivurin lämmitysjärjestelmän investoinnin kannattavuus erilaisilla polttoaineen hinnoilla. Investointi on taloudellisesti mielekäs, kun sen nettonykyarvo on $>0$. 
Taulukko 3. Kiinteän polttoaineen lämpölaitosinvestoinnin kassavirtojen nykyarvojen erotus öljylämpölaitoksen kassavirroista.

\begin{tabular}{llllllll} 
& \multicolumn{7}{c}{ Öljyn hinta snt / } \\
& $40 \mathrm{snt} / 1$ & $52 \mathrm{snt} / 1$ & $60 \mathrm{snt} / 1$ & $65 \mathrm{snt} / 1$ & $75 \mathrm{snt} / 1$ & $85 \mathrm{snt} / 1$ \\
\hline & $10 € / \mathrm{MWh}$ & -14362 & -2611 & 5223 & 10119 & 19912 & 29704 \\
& $15 € / \mathrm{MWh}$ & -19806 & -8055 & -221 & 4675 & 14468 & 24261 \\
& $20 € / \mathrm{MWh}$ & -25250 & -13499 & -5665 & -769 & 9024 & 18817 \\
Kiinteän & $23 € / \mathrm{MWh}$ & -28516 & -16765 & -8931 & -4035 & 5758 & 15550 \\
polttoaineen hinta & $25 € / \mathrm{MWh}$ & -30694 & -18943 & -11109 & -6212 & 3580 & 13373 \\
& $27 € / \mathrm{MWh}$ & -32871 & -21120 & -13286 & -8390 & 1403 & 11195 \\
& $29 € / \mathrm{MWh}$ & -35049 & -23298 & -15464 & -10567 & -775 & 9018 \\
& $31 € / \mathrm{MWh}$ & -37227 & -25475 & -17641 & -12745 & -2952 & 6840
\end{tabular}

Kokeilimme laskea myös siten, että olemassa oleva öljykäyttöinen kuivuri muutettaisiin kiinteällä polttoaineella toimivaksi. Kannattavuus tässä edellyttäisi sitä, että öljyuunin uusiminen olisi muutenkin edessä (uusintainvestointi) ja öljyn hinta nousisi pysyvästi yli tason $78 \mathrm{c} / 1$ (hake 20 e/MWh). Tuolla tasollahan käytiin jo vuoden 2008 aikana.

Tuloksia tarkastellessa kannattaa muistaa, että esitetty laskelma on tehty vain yhden laitevalmistajan antamin tiedoin. Kiinteän polttoaineen lämpölaitoksen voi saada myös tässä esitettyä konttiratkaisua edullisemmin, mikäli itse pystyy tekemään lämpölaitoksen rakennustyöt. Tällä hetkellä markkinoille on tulossa myös toinen kotimainen kuivurivalmistaja, joka tarjoaa kiinteillä polttoaineilla toimivaa ilmalämmitysuunia vapaavalintaisella polttoaineen syöttölaitteella ja siten, että viljelijä itse vastaa uunihuoneen rakentamisesta.

\section{Yhteenveto}

Suurin osa Suomessa tuotetusta viljasta on rehuviljaa, joka voitaisiin säilöä tuoreena ilmatiiviisti tai murskesäilönnällä. Tuoresäilönnän kustannukset ovat vain noin puolet lämminilmakuivauksen kustannuksista. Tuoreena säilötty vilja sopii lähinnä vain tilojen omaan käyttöön. Leipä- ja siemenvilja sekä keskusliikkeiden kautta myytävä rehuvilja täytyy lähes aina kuivata. Kylmäilmakuivaus sopii parhaiten pienemmille, omaan rehukäyttöön viljaa tuottaville tiloille.

Lämminilmakuivaamon suunnittelussa, rakenteissa, käytössä, säädöissä ja huollossa on useita kohteita, jotka hyödyntämällä kuivumista voidaan tehostaa ja säästää energiaa. Suurempi askel on vaihtaa lämmöntuotantoon käytetty polttoöljy kotimaiseen kiinteään polttoaineeseen. Puuhakkeen ja turpeen polttamiseen soveltuvat polttolaitteet ovat kehittyneet huomattavasti viime vuosina. Automatiikan ansiosta niiden toimivuus ja säädettävyys lähestyvät öljypoltinten tasoa. Kiinteällä polttoaineella toimivan lämpökeskuksen hankintahinta on korkea, koska mekaniikkaa, automatiikkaa ja tilaa tarvitaan enemmän kuin vastaavan tehoisessa öljylämpöjärjestelmässä. Laitoksen hankintahintaa kompensoivat kiinteiden polttoaineiden öljyä matalammat hinnat. Puuhakkeen hinta $(€ / \mathrm{MWh})$ on vain $20-40 \%$ polttoöljyn hinnasta.

Laadituissa investointilaskelmissa investointi ostohaketta käyttävään kiinteän polttoaineen lämpökeskukseen osoittautui kannattavaksi öljyn hinnan kohotessa yli $66 \mathrm{c} / 1$. Oman hakkeen tai palaturpeen käyttö olisi öljyä edullisempaa jo öljyn hinnan ylittäessä 55 - $58 \mathrm{c} / 1$. Energian hintasuhteiden muutokset, kiinteän polttoaineen lisätyöntarpeen ja varastotilatarpeen arvottaminen tuovat oman haasteensa investointipäätöksen tekemiseen. Selvää on, ettei käyttökelpoista öljylämmitysjärjestelmää kannata monestikaan lähteä muuttamaan kiinteillä polttoaineilla toimivaksi, ennen kuin öljyuunin uusinta on muutenkin edessä. Tilanne voi olla toinen, mikäli kuivurin läheisyydessä on suuritehoinen maatilakeskuksen lämpökeskus. Tällöin lämmönsiirtokanaalia ja radiaattoria käyttämällä voidaan kiinteiden polttoaineiden alhaisista hinnoista päästä hyötymään jo suhteellisin pienin investoinnein. 


\section{Lähteet:}

Ahokas, J. \& Koivisto, K. 1983. Energiansäästö viljankuivauksessa. Vakolan tutkimusselostus 31. Valtion maatalouskoneiden tutkimuslaitos. $89 \mathrm{~s}$.

Brealey, R.A., Myers, S.C. \& Allen, F. 2006. Corporate Finance. McGraw-Hill/Irwin New York 2006.

Koskiniemi, E. 2009. Kannattavuus. Teoksessa: Koskiniemi, E. (toim.). Viljankuivaus kotimaisella polttoaineella-opas. Metsäkeskukset: 24 - 25. http://www.puulakeus.net/docs/109-Ne6-viljankuivausopas.pdf

Lötjönen, T. \& Pentti, S. 2005. Kuivausteknologia. Teoksessa: Palva, R., Kirkkari, A-M. \& Teräväinen, H. (toim.). Viljasadon käsittely ja käyttö. Tieto tuottamaan 108: Maaseutukeskusten Liiton julkaisuja 1012: 34-54.

Palva, R., Kirkkari, A-M. \& Pentti, S. 2006. Viljan kuivauksen ja varastoinnin kustannukset. Työtehoseuran maataloustiedote 4 / 2006, nr. 589.

Palva, R. \& Lötjönen, T. 2005. Viljasadon korjuu- ja käsittelykustannukset. Teoksessa: Palva, R., Kirkkari, AM. \& Teräväinen, H. (toim.). Viljasadon käsittely ja käyttö. Tieto tuottamaan 108: Maaseutukeskusten Liiton julkaisuja 1012: $76-81$.

Palva, R. 2009. Konetyön kustannukset ja tilastolliset urakointihinnat. TTS tutkimuksen tiedote 3 / 2009. nr. 612.

Suomi, P., Lötjönen, T., Mikkola, H., Kirkkari, A-M. \& Palva, R. 2003. Viljan korjuu ja varastointi laajenevalla viljatilalla. Maa- ja elintarviketalous 31, 100 s. +1 liite. http://www.mtt.fi/met/pdf/met31.pdf 